\title{
IAMJ
}

INTERNATIONAL

AYURVEDIC

MEDICAL JOURNAL

ISSN: 23205091

Impact Factor: 5.344

Review Article

ISSN: 23205091

\section{TIME OF DRUG ADMINISTRATION IN AYURVEDA: CHRONOTHERAPY}

\author{
Mayank Srivastava ${ }^{1}$, Nitin Pandey $^{2}$ \\ ${ }^{1}$ Asst Prof. \& HOD, Dept. of Kaumarbhritya, Main Campus, Uttarakhand Ayurveda University, Harrawala, \\ Dehradun, Uttarakhand, India \\ ${ }^{2}$ Prof. \& HOD, Dept. of Kaya Chikitsa, Himalayiya (PG) Ayurvedic Medical College \& Hospital, Dehradun, \\ Uttarakhand, India
}

Email: drmayanksri@gmail.com

https://doi.org/10.46607/iamj0807292020

(Published online: July 2020)

Open Access

(C) International Ayurvedic Medical Journal, India 2020

Article Received: 14/07/2020 - Peer Reviewed: 16/07/2020 - Accepted for Publication: 16/07/2020

Check for updates

\begin{abstract}
Ayurveda is ancient machine of Indian medicine. So many principles are located here regarding to deal with sicknesses. Time of drug administration (Aushadha Sevan Kaala) is one in all them. The very last aim of Chikitsa is to reap equilibrium in Doshas and Dhatu samya, that's best by using given proper Aushadhi (Drug) in right time. Effectiveness of the drug administered depends on the time it's far taken. Aushadha Kala being a good deal flexible can be followed in line with the need of a person for purchasing preferred effects. Chronotherapy includes changing the timing of medication management to enhance the general manager of a sickness and to reduce remedy facet-outcomes and is an emerging concept inside the area of therapeutics. In various Ayurvedic texts, Acharyas had defined Aushadha Sevana Kalas in step with the biological clock for accomplishing the equilibrium between the Doshas and Dhatus which in the long run ends in swasthya (exact health).
\end{abstract}

Keywords: Aushadha Sevan Kaala, Doshas, Dhatusamya, Chronotherapy

\section{INTRODUCTION}

Chronotherapeutic, or chronotherapy, is the synchro-

nization of medication with the biological rhythms of disease activity and symptom intensity. ${ }^{[1]}$ Chronotherapy is an method that fulfils the criteria of drug 
transport at a particular time as according to the pathophysiological want of the disorder, to enhance patient compliance. Chronotherapeutic is an emerging approach inside the treatment of various biological issues. Circadian rhythms are the crucial factor inside the biological cycle through which the drug dosing have to be matched with the rhythms of the illnesses for a success treatment of the contamination or the disease

The effectiveness of many drugs varies depending on the dosage administration time associated with 24 hours biological rhythm under the control of circadian clock. ${ }^{[2]}$ Ayurveda has already been defined the variation in physiology and patho-physiological elements together with healing interventions and manner according to circadian rhythm for the maximum effectiveness and to limit the side results e.g. Disorders due to Vata, Pitta and Kapha Dosha get aggravated during rainy, autumn and winter season respectively, ${ }^{[3]}$ seasonal Panchakarma during aggravation of doshas, ${ }^{[4]}$ etc.

In Ayurveda, all physiological and pathological phenomenon depend upon delicate balance of doshas and to exactly adjust doshic biological clocks modifications are made inside the form of dinacharya and ritucharya. The idea of ritucharya implies dietetics, habits and behavioural adjustments to seasonal modifications. Ritucharya pursuits at fitness upkeep in all seasons via a balanced country of doshas i.e. Doshas samya. A balanced (and nicely adjusted) eating regimen is the conditions for maintaining the most excellent state of doshas.

Time specific administration of drugs outcomes in top-rated pharmacological utility of the drug. Bheshaja sevana kala a classical idea is currently studied as chronotherapy within the current science gaining its importance in clinical practice.

Acharya Vagbhata mentioned that- "Kalo bhaishajya yoga krt" ${ }^{[5]}$ means for every action in the Universe is bound with the causative association of kala and hence Aushadha employed in a proper Kaala will result in expected kaarya.

Thus, to get the desired effect of the treatment consideration of that particular time for administration of medicine is valuable. Synchronizing the drug therapies with body rhythms will indeed improve the result of treatment and that is studied presently under "chronotherapeutics". ${ }^{[6]}$

Aim

- To explore and re-evaluate the various Ayurvedic concepts and principles related to time of drug administration (Ausadh sevan kaala) in Ayurveda.

- To explore the relationship between Kaala and Ausadh sevan kaala.

- To explore the clinical approach for time of drug administration in Ayurveda.

\section{Materials \& Methods}

Materials related to Ausadh, kaala, Ausadh sevan kaala, Chronotherapeutics, Chronotherapy and other related topics have been collected. The main Ayurvedic texts used in this study are Charak Samhita, Sushruta Samhita, Ashtang Samgraha, Ashtang Hridaya, and Sharangdhar Samhita etc. We have also referred to the modern books and searched various websites to collect information on the relevant topics.

\section{DISCUSSION}

\section{Vitality of Kaala}

Ayurveda has given great importance to the kaala (time) for the swastha (healthy) as well as the roga (disease). From the basic dina charya (daily regimen), ritu charya (seasonal regimen), dosha kala (time of each dosa), avasthapaka (stages of digestion) kaala, dhathu poshana (process of nourishment) kaala, the process of ageing(Jara), samprapti (pathogenesis) in a disease to its Chikitsa(treatment), all the factors depends on time e.g.

$>$ Kaala as a Nidana for $\operatorname{rog} a^{[7]}$

$>$ Kalaja and Akalaja vyadhi ${ }^{[8]}$

$>$ Kala in Sadhyasadhyata (prognosis) ${ }^{[9]}$

$>$ Importance of kala in Arishta (bad prognosis) ${ }^{[10]}$

$>$ Importance of kala in Chikitsa ${ }^{[1]}$

$>$ Importance of kala in collection of drugs ${ }^{[12]}$

$>$ Aushadha sevana kala ${ }^{[13]}$

It has already been mentioned in the classics that while treating a disease success can be achieved only when there is proper combination of Desha (region), Kaala (time), Pramana (dosage), Satmya (whole- 
someness), Asatmya (unwholesomeness), Pathya (useful), and Apathya (harmful) ${ }^{[14]}$ among these, Kaala acquires second position, which shows the importance of Kaala in Chikitsa. As per Ayurvedic texts Kaala means:

1. Shad Aveksha Kaala (Six observatory aspects of time) $-^{[15]}$

Table1: Shad Aveksha Kaala

\begin{tabular}{|l|l|}
\hline Dina (Different parts of the day) & Rogi (Patient) \\
\hline Aushadha (Drugs) & Vyadhi (Disease) \\
\hline Jeerna Laxana (stage of the digestion of the food) & Ritu (nature of the season) \\
\hline
\end{tabular}

2. Dasha Bheshaja Kaala (Ten types of times for the administration of medicine) ${ }^{[16,17]}$

Table 2: Relation between different time phase -doshas- digestion stage

\begin{tabular}{|l|l|l|l|l|}
\hline \multicolumn{4}{|l|}{ Relation Between Different Time Phase -Doshas- Digestion Stage } \\
\hline 1 & Doshas & Vaata & Pitta & Kapha \\
\hline 2 & Vaya (Age) & Old Age & Young Age & Childhood \\
\hline 3 & Day & 2pm-6pm & 10am-2pm & 6am-10am \\
\hline 4 & Night & 2am-6am & 10pm-2am & 6pm-10am \\
\hline 5 & Digestion stage & Pakvavastha (End stage) & $\begin{array}{l}\text { Vidagdhavastha (Middle } \\
\text { stage) }\end{array}$ & Amavastha (Initial stage) \\
\hline
\end{tabular}

Table 3: Relation between different season/ kaala and bala (immunity)

\begin{tabular}{|l|l|l|l|l|}
\hline \multicolumn{4}{|l|}{ Relation } & Between Different Season/ Kaala And Bala (Immunity) \\
\hline 1 & Kala & Hina Bala (Debility) & $\begin{array}{l}\text { Madhyabala } \\
\text { (Medium Strength) }\end{array}$ & $\begin{array}{l}\text { Srestha Bala } \\
\text { (Maximum Strength) }\end{array}$ \\
\hline 2 & Adanakala & Grisma & Vasanta & Sisira \\
\hline 3 & Visarga Kala & Varsa & Sharada & Hemanta \\
\hline
\end{tabular}

The three bodily humors (Vaata-Pitta-Kapha), Agni status (power of digestion and metabolism) and Bala (Immunity) follow the biological clock along with the environmental cues and predominance of this organic entity range in different seasons. Any trade inside the normal seasonal property will desynchronize these rhythm upshots in manifestation of diseases. Ayurveda classics have well defined the variation in presentation of disorders in accordance with day, night, seasons and mealtime to get the maximum effectiveness of drug. Similarly for the selection of a proper drug, not only the strength of disease and patient, age, constitution(Prakriti), psychological issue (Satva), digestive capacity (Agni), accustoms of patient (Satmya), involved Dosha and Dushya were taken into consideration however also the time of administration of drug has also been pondered over.

\section{Time of drug administration (Ausadh sevan kaala)} Acharya Charaka has mentioned that proper drug administration includes appropriate dosage and timing; and that confirms the success of the treatment.

"Matra kalasraya yuktib, Sighiryauktou Pratisthita "(C.S.Su 2/16)

Likewise, Vagbhata while stressing the importance of kala-ausadha sambandha (time - drug relationship) says that time potentiates efficiency of drugs moreover a drug used at inappropriate time is not going to be beneficial.

"Nahyapraptati ta kalamousadhamYougikam bhavati" (A.S. Su 23/12)

As per various ancient scholars, Aushadha Sevana Kala (time) have been classified as below:

Charaka - 10 Sushruta - 10 Ashtanga Hrudya - 10

Ashtanga Sangraha - 11, Sharangdhara - 05 
Table 4: Ausadh sevan kaala as per different authors ${ }^{[18,19,20,21,22]}$

\begin{tabular}{|c|c|c|c|c|}
\hline Charaka - chi. 30 & $\begin{array}{l}\text { Ashtanga Hrudaya - } \\
\text { Su.13 }\end{array}$ & $\begin{array}{l}\text { Ashtanga Sangraha - } \\
\text { Su. } 23\end{array}$ & $\begin{array}{l}\text { Sushruta } \\
\text { Uttara } 64\end{array}$ & Sharangadhara - Purva 2 \\
\hline Pratah Niranna & Abhakta & Abhakta & Abhakta & Suryodayajatah \\
\hline Bhuktadau & Pragbhakta & Pragbhakta & Pragbhakta & $\begin{array}{l}\text { Divasabhojane } \\
\text { a)BhojanaPurva } \\
\text { b) Sagrasa } \\
\text { c) BhojanaMadhya } \\
\text { d)BhojanaPashchat }\end{array}$ \\
\hline Bhuktamadhye & Madhyabhakta & Madhyabhakta & Madhyabhakta & $\begin{array}{l}\text { Sayambhojane } \\
\text { a)Grasantare/Grase } \\
\text { b)Bhojanapashchat }\end{array}$ \\
\hline $\begin{array}{l}\text { Bhuktapaschat } \\
\text { after lunch (pratah) }\end{array}$ & pashchadbhakta & Adhobhakta & Adhobhakta & Nishi \\
\hline $\begin{array}{l}\text { Bhuktapaschat } \\
\text { after dinner (sayam) }\end{array}$ & Nishi & Antarabhakta & Antarabhakta & \\
\hline Muhurmuhu & Muhurmuhu & Muhurmuhu & Muhurmuhu & \\
\hline Samudga & Samudga & Samudga & Samudga & \\
\hline Bhaktasanyukta & Sabhakta & Samabhakta & Sabhakta & \\
\hline Sagrasa & Sagrasa & Sagrasa & Grasa & \\
\hline Grasantara & Grasantara & Grasantara & Grasantara & \\
\hline & & $N i s h i$ & & \\
\hline
\end{tabular}

Description and clinical indications of Ausadh Sevan Kaala

a) Abhakta /Niranna (empty stomach):

- Administration of Aushadh alone in empty stomach

- No interaction with food

Probable mode of action- As drug administered in empty stomach so that it directly interacts with agni. As in abhakta kaala stomach is devoid of kapha thus the agni digests the drug completely and one gets the maximum benefits.

\section{Indications-}

- Patients having good status of Agni

- In case of Balwan Rogi with Balavan Vyadhi.

- Used as Rasayana.

- In case of Kaphaja disorders etc.

\section{Contraindications-}

- In case of Children, Pregnancy, Female patients

- In Doshakshaya and Dhatukshaya

b) Pragbhakta/ Bhuktadau (before meals)

- Administration of Ausadh just before the intake of food
- Ausadh intake should be immediately followed by food (Hemadri)

- The Ausadh directly acts on the Amashaya and the vitiated Doshas ${ }^{[23]}$

Probable mode of action- As drug is used just before the food, So, its first interaction is with agni, leads to quick metabolism and also there is less chance of any toxic effects of drug as food follows the drug. Food also reduces the expulsion of drug, so can be used in debilitated patients. Apana Vayu is in active state during this kaala so it's a right time of drug administration for Apana Vayu vikriti.

\section{Indications-}

- Disorders of Apanavayu

- Diseases of lower body parts

- Obesity/Fat disorders etc.

c) Madhyabhakta (in between meals)

- Ausadh is administered in between the meal.

- As per Chakrapani and Indu, half of the food is taken initially, followed by Ausadh administration, and again followed by remaining food. 
- Acharya Sushruta explained that due to Avisaari Bhaava (not spread) of Aushadha, it acts on Madhya Deha Rogas ${ }^{[24]}$

Probable mode of action- In this case ausadh is taken in between the meals so it is covered by both upper and lower ends and cannot spread so act locally for sthanika doshas. During this period Samana vaayu is stimulated that enhances the paka of ausadh.

\section{Indications-}

- Vitiation of Samanavayu -Mandagni -Paittika disorders

- Koshthagatavyadhi-Shula-Gulma-Grahani

d) Pashchadbhakta/ Adhobhakta (after lunch and dinner)

- Ausadh is administered after meals (after lunch \& dinner).

- Hemadri \& Indu-Ausadh is to be administered immediately after meals

Probable mode of action- In this kaala ausadh is administered after meals i.e., after lunch \& dinner. After lunch, there is stimulation of Vyana Vayu and after dinner of Udana Vayu, So, they could be used in the respective disorders. As the site of vyaana vayu is considered to be hrudaya (heart). Acharyas have stated that as every flower bloom in the morning everyday similarly every morning heart also blooms, activating vyaana vayu in it. Thus, the medicine administered in the morning will reach hridaya and will act properly on vyana vaayu. The activity of vyana vaayu reduces in the night. The activities of vyana are then taken over by udana vaayu, thus the administration of ausadh after dinner helps to cure the diseases related with udana vata.

\section{Indications-}

- Disorders related with Vyana vayu-Udana vayu

e) Muhurmuhu (frequently administered)

- Aushadha is administered frequently regardless of Bhukta or Abuktavastha

- Bhukta and Abhuktavastha are chosen according to the power of patient

Probable mode of action- In order to get immediate relief, the Ausadh is given frequently, and that maintained its plasma concentration and make it more bioavailable. The Kala provides an opportunity to admin- ister higher therapeutic dose of ausadha to pacify the aggravated Doshas.

\section{Indications-}

- Preferred during acute conditions

- Pranavaha-Udakavaha -Annavahastrotogata disorders

\section{f) Antarbhakta (after digestion of meal in noon)}

- The administration of ausadha in between two meals is considered as Antarabhakta

- Ausadh is to be taken in the afternoon and after digestion of medicine, again food is to be given to the patient in the evening

- As per Indu ${ }^{25}$, first Antara Bhakta is during day, and the next one is 1 Yaama after evening food. This is equivalent to Nishi.

Probable mode of action- Due to madhyanha i.e. Pittakala, Agni is in a stimulated condition. So, ausadha is properly metabolized and produces desired effect.

\section{Indications-}

- Disorders of Vyana vayu

\section{g) Samudga (just before and after meal)}

- Ausadha is administered at the time immediate before and after meals

- Indu and Hemadri specify that ausadha should be consumed immediately in relation to food

Probable mode of action- As ausadha is administered at the time immediate before and after meals so it acts on Vyana, Apana and Udana Vayu. Samudga Kala probably helps in the therapeutic activity of the ausadha in correcting the pathogenesis and establishing Anulomana of Vata Dosa.

\section{Indications-}

- Disorders related with Vyana-Apana-Udanavayu

\section{h) Sabhakta (mixed with food)}

- Ausadha is administered with food

- According to Indu-Ausadha is processed or cooked along with food or it is given with food

- Kashyapa mentions it to be Bala and Agni Rakhshaka ${ }^{[26]}$

Probable mode of action- As ausadha is taken by mixing or cooked along with food, so, when the food is digested and gets converted into aahaara rasa, the ausadha also gets digested and its extract comes with 
aahara rasa. This medicated aahara rasa gets circulated in the body and helps to cure diseases all over the body.

\section{Indications-}

- Arochaka, aruchi, sarvangasamshrita vyadhis etc

- Useful in women, old, children, debilitated patients

\section{i) Sagrasa (with each and every bite of food)}

- Ausadha is given with each and every bite of food Probable mode of action- As ausadha is given with each bite of food, enhances its absorption right from buccal mucosa and offers rapid onset of action. $\mathrm{Sa}$ grasa kaala ausadh stimulates the Pranavayu.

\section{Indications-}

- Specially indicated for Leha, Churna, Vati Kalpana

- Prana vayu disorders

j) Grasantare (in between two bites of food)

- Intake of ausadh between the bolus of food

- In Ashtanga Hrudaya, Sarvanga Sundari Teeka it is clearly mentioned that Aushadhi is administered between bolus of food but in Ayurveda Rasayana Teeka it is said as Graasa Sampruktamaushadham [27]

Probable mode of action- helps in correcting the Gati (activity) Vikruti of Vata Dosha by promoting Anulomana of Vata Dosha. The process of deglutination is supervised by prana vaayu. Thus, the medicine taken along with each bolus of food will come in contact with prana and will help to cure prana related diseases.

\section{Indications-}

- Disorders of Prana Vayu

- In Hridya roga ${ }^{[28]}$

k) Nisha (before sleep)

- Ausadh is administered after digestion of food consumed

- According to Indu, the exact Nisa Kala is the time after the evening meal has digested and 3 hours have passed.

- In Shaarangadhara Samhita, Deepika Commentary, it is mentioned that the timing of administration of medicine is 1 Yaama after evening meals. ${ }^{[29]}$
- Chiraparinamana (long lasting action) of the Shamana Aushadhi is achieved as no food intake occurs until the next morning. ${ }^{[30]}$

Probable mode of action-the Nisa Kala, in which there is Kapha vrddhi due to Kala Prabhava is an aid to the activity of ausadha used and ausadha admits elective affinity (Gamitva) towards the part, above the neck. Selective action of the ausadha towards the urdhvajatrugata parts because the Adhara gati of ausadha is prevented by food.

\section{Indications-}

- Urdhvajatrugata Disorders

- Indicated for Vamana, Dhumapana.

\section{CONCLUSION}

Acharya Charaka says that Aushadha given at appropriate Kala (time) is more efficacious than one given at inappropriate Kala. The effect of a drug depends on the dosage administration time. In Ayurveda, it has been mentioned that the predictable variations in bodily functions during a day, season and age alters the severity of disease symptoms, results of diagnostic tests and effects of drugs. The drug release in body and its specific action on specific dosha or disease conditions vary with the Circadian variation of dosha and disease symptoms. Chrono pharmacology and Chronotherapeutic has emerged an important area for research for medical fraternity as its correct knowledge helps doctors to treat patient more effectively. Hence the success of treatment always depends upon the time of drug administration.

\section{REFERENCES}

1. https://www.merriam-

webster.com/medical/chronotherapeutics. Accessed 1 Jul. 2020.

2. 2. Davidson's Principles \& Practice of medicine, Christopher Haslett, Edwin R. Chilvers, John A.A. Hunter, Nicholas A. Boon, 20th edition, Churchill Livingstone, 2009, p. 670.

3. Dwivedi LD, Dwivedi BK, Goswami PK. editor. Charak Samhita of Agnivesha with Chakrapanidutta and Gangadhara commentary, Sutrasthana; Tasyash- 
itiyamadhyaya: 6/22,34, 41, 3rd ed. Varanasi: Chowkhambha Krishnadas Academy;2014. p. 167-170.

4. Pandit Parashuram Shastry vidyasagar, editor. Sharangadhara Samhita Uttaratantra: 3/1, 5th ed.Varanasi: Chaukambha Orientalia, 2002. p.304.

5. Acharya Vagbhata. Astanga Sangraha Sutrasthan, Volume I, Translated by K Srikanthamurthy, 1/45,2nd ed. Varanasi: Chaukhamba Orientalia, 1999.

6. Jeeth A, Aloknath DD, Sujnana VS, Shreevathsa. Utility of Bheshaja Sevana Kala - Open End Comparative Clinical Trial. J of Ayurveda and Hol Med (JAHM) 2014; 2(7):4-7.

7. Sharma. R. K, Dash. B (editor). Charaka Samhita, Sutra sthana: 11/37, Varanasi: Chowkamba Sanskrit Series; Reprint 2007.p. 221.

8. Murthy.K.R.S. Susrutha Samhita, Sutra sthana:24/7, Varanasi: Chowkamba Orientalia; Reprint 2008.p. 177.

9. Sharma.R.K, Dash.B (editor). Charaka Samhita, Sutra sthana,10/11-18, Varanasi: Chowkamba Sanskrit Series; Reprint 2007.p. 197-9.

10. 10.Ibid, Indriya sthana, 11/3,p. 577.

11. Ibid, Vimana sthana, 1/3,p.112.

12. Ibid, Kalpa sthana,1/10,p.10.

13. Murthy.K.R.S. Susrutha Samhita, Uttarasthana,64/65, Varanasi: Chowkamba Orientalia; Reprint2008. p. 431.

14. Pandey GS, editor. Agnivesha, Charaka, Dridhabala, Charaka Samhita, Chikitsa Sthana: 30/293. 8th ed. Varanasi: Chaukambha Sanskrit Samsthan, 2004.p.789.

15. Ibid,30/ 296-304; 789-90.

16. Ibid,30/ 298-304; 790.

17. Paradkar HS, editor, Vagbhata, Ashtanga Hridaya, Sutra Sthana: 13/38. Reprint ed. Varanasi: Chaukambha Surbharati Prakashan, 2002.p. 219.

18. Shulka. V, Tripathi. R, editors, Charaka Samhita (Vaidyamanorama Hindi Commentary), Chikitsa sthana: 30/296, Vol. II. 20th ed. Varanasi: Chaukhambha Sanskrut Prakashan:1994. p. 881-882.

19. Tripathi Brahmananda, editor, Astanga hrdaya (Nirnala Hindi Commentary) Sutra sthana: 13/37. 2nd ed. Varanasi: Chaukhamba Surbharati Prakashan.p.190-191.

20. Tripathi Ravidatta, editor, Ashtanga Sangraha, Sutra sthana: 23/12.1st ed. Varanasi: Chaukhamba Sanskrit Pratishithan; 2001. p. 428.

21. Sharma Anantram, editor, Sushruta Samhita (Susrutavimarsa Hindi commentary), Uttartantra: 64/65. Vol. II. 1st ed. Varanasi: Chaukhambha Surbharati Prakashan; 2004. p. 571-572.
22. Tripathi Brahmananda, editor, Sharangdhara Samhita, Purvakhanda: 2/1-12. $2^{\text {nd }}$ ed. Varanasi: Chaukhamba Sanskrut Prakashan:2006. p.23-24.

23. Ibid, p.24.

24. Jadavji Trikamji Acharya, editor, Sushruta samhita with Nibandhasangraha Commentary, Rasbhedavikalpopakrama. Bombay: Nirnaya Sagar press:1915. p. 705 .

25. Murthy Srikantha, editor, Ashtanga Sangraha Bheshajaavachaaraneeyah. Varanasi: Chaukambha Orientalia: 2016.p. 415-417.

26. Bhishagacharya Srisatyapala, editor, Vriddha jivaka. Kashyapa Samhita with Vidhyodhini commentary, Bhaishajopakramaneeya adhyaya. Varanasi: Chaukambha Sanskrit Samsthan: 2006.p.244.

27. Paradkar HS, editor, Astanga hrdaya with Sarvangasundra \& Ayurveda Rasayana Commentary, Doshopakramaneeyaadhyaya. $6^{\text {th }}$ ed. Bombay:Nirnaya sagar press:1939.p. 218-219.

28. Tripathi Ravidatta,editor Vagbhata. Ashtanga Sangraha. Sutra sthana, 1/45 1st ed. Varanasi: Chaukhamba Sanskrit Pratishithan; 2006. p.10.

29. Parashurama shastry Vidyasagar, editor, Sharangadhara samhita with Dipika \& Gudaartha Deepika commentary Purva khanda, $2^{\text {nd }}$ chapter, $2^{\text {nd }}$ ed. Bombay: Nirnaya sagar press: 1931.p. 16-17.

30. Manjunatha, Sasanoor T Importance of Bhaishajya Kala in the Management of Diseases, International Journal of Ayurvedic and Herbal Medicine,2012, 2: 353-365.

\section{Source of Support: Nil \\ Conflict of Interest: None Declared}

How to cite this URL: Mayank Srivastava \& Nitin Pandey: Time Of Drug Administration In Ayurveda: Chronotherapy. International Ayurvedic Medical Journal \{online\} 2020 \{cited July, 2020 $\quad$ Available from: http://www.iamj.in/posts/images/upload/3996 4002.pdf 